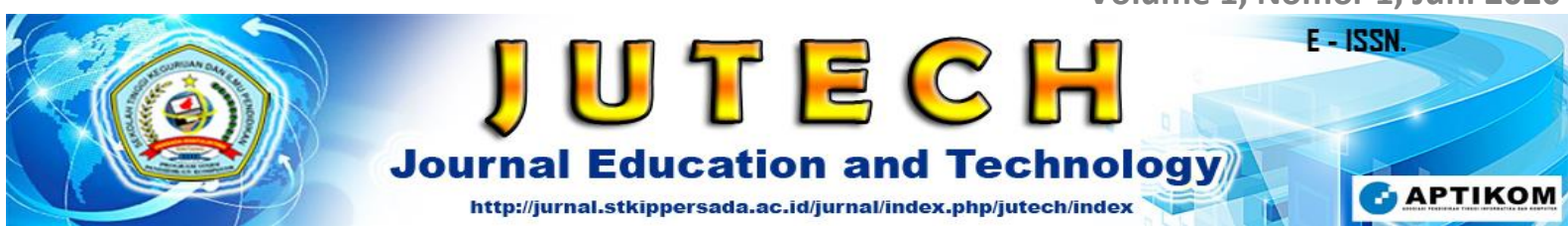

\title{
PENGEMBANGAN MEDIA PEMBELAJARAN INTERAKTIF BERBASIS MICROSOFT POWER POINT
}

\author{
Anyan $^{1}$, Benediktus Ege ${ }^{2}$, Hendry Faisal ${ }^{\mathbf{3}}$ \\ ${ }^{1}$ Program Studi Pendidikan Komputer, STKIP Persada Khatulistiwa Sintang \\ ${ }^{2}$ Program Studi Pendidikan Biologi, STKIP Persada Khatulistiwa Sintang \\ ${ }^{3}$ Program Studi Pendidikan Guru Sekolah Dasar, STKIP Persada Khatulistiwa Sintang \\ email: anyanright@gmail.com, ama_tamo@yahoo.com, h.faisal34@yahoo.com
}

\section{Informasi Artikel}

\section{Riwayat Artikel :}

Disubmit : 21 April 2020

Direvisi : 7 Mei 2020

Diterima : 10 Mei 2020

Dipublikasi : Juni 2020

Keywords:

Interactive Media, Multimedia, Power Point, Interactive Learning

Kata Kunci:

Media Interaktif,

Multimedia, Power Point, Pembelajaran Interaktif

\section{ABSTRACT}

The limitation of supporting media in the teaching and learning process causes the teaching and learning process to be less than optimal. To overcome this, it can be done by using interactive learning media based on Microsoft Power Point. The purpose of this study is to produce interactive PowerPoint learning products Microsoft Power Point to improve student learning outcomes in Thematic learning of the subtheme of the Beauty of the Nature of My Country in grade IV elementary school. The research method used is the published Borg and Gall research: preliminary studies, model development and model trials. The results showed that the interactive learning media developed was declared feasible. Media validation and material validation showed an average score of $82.50 \%$ and 79.16\%. Student responses to teaching materials scored $81.75 \%$ in small-scale trials on large-scale trials receiving scores of $85 \%$. The response teacher got a score of $71.7 \%$ and $89.13 \%$. Based on the grades obtained, then the interactive learning media based on Microsoft Power Point is feasible to be applied to grade IV elementary school students.

\section{ABSTRAK}

Keterbatasan media pendukung dalam proses belajar mengajar menyebabkan proses belajar mengajar menjadi kurang maksimal. Untuk mengatasi hal tersebut dapat dilakukan dengan menggunakan media pembelajaran interaktif berbasis Microsoft Power Point. Tujuan penelitian ini menghasilkan produk media pembelajaran interaktif berbasis Microsoft Power Point untuk meningkatkan hasil belajar siswa pada pembelajaran Tematik subtema Keindahan Alam Negeriku di kelas IV SD. Metode penelitian yang digunakan adalah penelitian Borg dan Gall yang meliputi: studi pendahuluan, pengembangan model dan uji coba model. Hasil penelitian menunjukkan bahwa media pembelajaran interaktif yang dikembangkan dinyatakan layak. Validasi media dan validasi materi menunjukan nilai rata-rata skor sebesar $82,50 \%$ dan $79,16 \%$. Respon siswa terhadap bahan ajar interaktif memperoleh skor $81,75 \%$ pada uji coba skala kecil sedangkan uji coba skala luas memperoleh skor sebesar 85\%. Respon guru mendapat skor $71,7 \%$ dan $89,13 \%$. Berdasarkan nilai yang diperoleh, maka media pembelajaran interaktif berbasis Microsoft Power Point layak diterapkan pada siswa kelas IV sekolah dasar. 


\section{PENDAHULUAN}

Sistem pendidikan Nasional bertujuan untuk mewujudkan manusia Indonesia seutuhnya. Merujuk dari tujuan Sistem Pendidikan Nasional yang tertera dalam Undang-Undang No. 20 Tahun 2003, tujuan pendidikan sekolah dasar adalah meletakkan dasar kecerdasan, pengetahuan, kepribadian, akhlak mulia, serta ketrampilan untuk hidup mandiri dan mengikuti pendidikan lebih lanjut. Dengan demikian, pendidikan merupakan salah satu kebutuhan yang harus dipenuhi serta ditingkatkan, khususnya kualitas sumber daya pendidik dan peserta didik. Usaha peningkatan mutu pendidikan merupakan tanggung jawab bersama antara pemerintah, masyarakat, dan orang tua. Semua usaha ini akan berhasil jika pihak yang terkait dengan pendidikan akan bekerja sama menyatukan visi dan misi yang sama untuk peningkatan mutu pendidikan.

Perubahan kurikulum telah terjadi beberapa kali di Indonesia sebagai upaya peningkatan kualitas pendidikan. Saat ini sedang dikembangkan kurikulum 2013 yang diterapkan di sekolah mulai Tahun ajaran 2014/2015. Kurikulum 2013 menekankan pembelajaran tematik menjadi sebuah tuntutan dan kebutuhan pokok dalam proses belajar mengajar di sekolah dasar. Sedangkan pembelajaran tematik merupakan suatu model pembelajaran termasuk salah satu jenis model pembelajaran terpadu. Pembelajaran tematik memiliki satu tema aktual,dekat dengan dunia siswa, dan ada kaitannya dengan kehidupan sehari-hari. Tema berperan sebagai pemersatu kegiatan pembelajaran dengan memadukan berbagai standar kompetensi dan kompetensi dasar dari beberapa muatan pelajaran sekaligus. Adapun muatan pelajaran yang dipadukan adalah muatan pelajaran PPKn, Bahasa Indonesia, IPS, IPA, Matematika, Seni Budaya, dan Prakarya, serta Pendidikan Jasmani, Olah Raga, dan Kesehatan.

Kurikulum 2013 menggunakan buku pegangan siswa berupa buku tematik dan buku pendamping tematik untuk guru sebagai sumber belajar. Selain buku tematik sebagai sumber belajar, guru dituntut untuk mengaplikasikan materi tematik sesuai dengan lingkungan belajar yakni, dengan memanfaatkan penggunaan media yang bervariasi yang ada dikelas sebagai sumber belajar. Peran guru sangat penting dalam merancang pembelajaran sehingga kurikulum 2013 memiliki cakupan materi yang luas, maka membutuhkan banyak waktu dalam proses belajar.

Berdasarkan hasil observasi awal pada hari senin 9 April 2018 di kelas IV Sekolah Dasar Negeri 01 Ketungau Hilir, dapat diketahui bahwa sumber belajar yang digunakan dalam proses pembelajaran kurikulum 2013 yaitu buku pegangan siswa berupa buku tematik yang dimiliki setiap siswa dan buku pendamping tematik untuk guru. Pada proses pembelajaran dikelas, guru kurang mengaplikasikan materi pelajaran dengan 


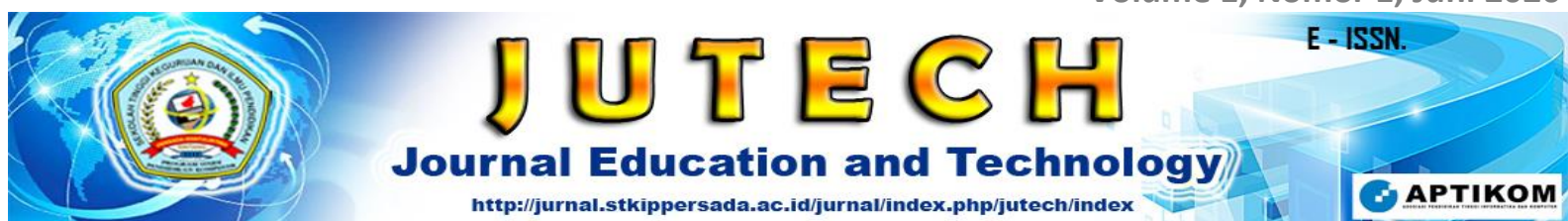

media yang ada di lingkungan kelas, sehingga siswa sulit memahami materi yang diajarkan. Namun tidak semua materi dapat dijelaskan dengan memanfaatkan media yang ada di lingkungan kelas. Seperti materi keindahan alam negeriku, guru merasa kesulitan dalam mencontohkan materi tersebut sehingga siswa sulit memahami materi yang diajarkan. Proses pembelajaran yang dilaksanakan guru juga masih bersifat konvensional dan gurunya yang mendominasi proses belajar mengajar sehingga menyebabkan siswa pasif dan bosan didalam kelas. Kreativitas guru dalam menyampaikan materi pelajaran sangat berperan penting dalam keberhasilan proses belajar.

Berkaitan dengan hal tersebut, maka untuk meningkatkan proses pembelajaran diperlukan sebuah media yang menarik untuk menumbuhkan semangat, minat, serta mengaktifkan siswa dalam proses kegiatan belajar mengajar di kelas. Salah satu alternatif mengatasi masalah yang cocok yaitu dengan media pembelajaran interaktif berbasis Microsoft Power Point akan membantu dalam menggabungkan semua unsur media seperti teks, gambar, suara bahkan video dan animasi sehingga menjadi sebuah media pembelajaran yang menarik. Bagi pengguna komputer, Microsoft Power Point adalah aplikasi yang lazim digunakan dalam kegiatannya terutama pada saat presentasi. Microsoft Power Point adalah suatu software yang akan membantu dalam menyusun sebuah presentasi yang efektif, professional, dan juga mudah.
Microsoft Power Point akan membantu sebuah gagasan menjadi lebih menarik dan jelas tujuannya jika dipresentasikan. Microsoft Power Point akan membantu dalam menggabungkan semua unsur media seperti teks, gambar, suara bahkan video dan animasi sehingga menjadi sebuah media pembelajaran yang menarik.

Berdasarkan latar belakang masalah yang telah dikemukakan, maka masalah umum dalam penelitian ini adalah "Bagaimana Pengembangan Media Pembelajaran Interaktif Berbasis Microsoft Power?

Tujuan umum dalam penelitian ini adalah untuk mendeskripsikan Pengembangan Media Pembelajaran Interaktif Berbasis Microsoft PowerPoint.

\section{METODE PENELITIAN}

Jenis penelitian ini merupakan Penelitian dan Pengembangan (Research and Development). R\&D merupakan jenis penelitian yang menghasilkan suatu produk bukan menguji sebuah teori. Pengertian tersebut sesuai dengan teori yang dikemukakan Borg \& Gall (1983: 772) "educational research and development $(R \& D)$ is a process used to develope and validate educational products.". Pengertian R\&D dari Borg \& Gall tersebut dapat diartikan bahwa Penelitian Pendidikan dan Pengembangan adalah sebuah proses yang digunakan dalam mengembangkan dan menguji sebuah produk pendidikan. 


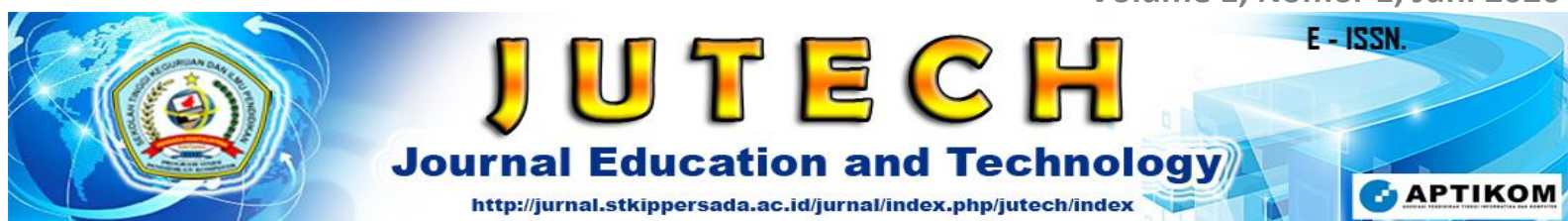

Produk yang dikembangkan dalam penelitian ini adalah Media Pembelajaran Interaktif berbasis Microsoft Power Point yaitu sebuah media yang mempermudah guru dalam menyampaikan informasi lebih cepat dan mudah dan dapat mempermudah siswa untuk memperoleh informasi yang efektif dan menarik minat siswa dalam proses pembelajaran. Menurut Sugiyono (2011: 407) penelitian dan pengembangan adalah metode penelitian yang digunakan untuk menghasilkan produk tertentu dan menguji keefektifan produk tersebut. Senada dengan Sugiyono, Sukmadinata (2010: 164) mendefinisikan penelitian dan pengembangan atau Research and Development (R\&D) adalah suatu proses atau langkah langkah untuk mengembangkan suatu produk baru atau menyempurnakan produk yang telah ada, yang dapat dipertanggungjawabkan. Penelitian dan pengembangan merupakan jenis penelitian yang berorientasi pada pengembangan produk. Memperhatikan uraian dari Sugiyono dan Sukmadinata disimpulkan bahwa penelitian yang dilakukan termasuk dalam penelitian dan pengembangan. Hasil dari penelitian ini nantinya adalah berupa produk media pembelajaran interaktif subtema keindahan alam negeriku.

Uji coba produk ini dilakukan sebanyak 2 kali, yaitu uji coba terbatas dan uji coba produk secara luas. Uji coba produk secara terbatas dilakukan pada siswa kelas IV SD Negeri 03 Sintang, dengan diambil sampel sebanyak 16 orang. Uji coba dilakukan dengan memberikan media pada siswa, kemudian mengumpulkan data melalui angket tanggapan siswa, angket tanggapan guru dan hasil belajar siswa.

Kemudian setelah direvisi, uji coba dilanjutkan dengan uji coba produk secara luas. Uji coba produk secara luas diberikan pada siswa Kelas IV SD Negeri 01 Ketungau dengan diambil sampel seluruh siswa sebanyak 26 orang. Uji coba skala luas dilakukan dengan pelaksanaan pembelajaran menggunakan media yang telah dikembangkan, kemudian mengumpulkan data melalui angket tanggapan siswa, angket tanggapan guru dan hasil belajar siswa. Alasan peneliti ingin meneliti di kedua sekolah tersebut karena sama-sama kurang memadainya media pembelajaran dalam kegiatan belajar mengajar dan juga tempat di kedua sekolah tersebut tidak terlalu jauh untuk di lakukan penelitian.

\section{HASIL DAN PEMBAHASAN}

Hasil penelitian dan pengembangan media pembelajaran interaktif dilakukan dengan prosedur pengembangan melalui 7 tahap yaitu: analisis kebutuhan, penentuan KI, KD dan Flowchart, pengembangan pembelajaran SD dan media pembelajaran SD, telaah pakar, tahap uji lapangan/implementasi, analisis hasil uji coba, dan produk media pembelajaran interaktif.

Hasil validasi ahli materi dan ahli media dijadikan dasar untuk merevisi media 


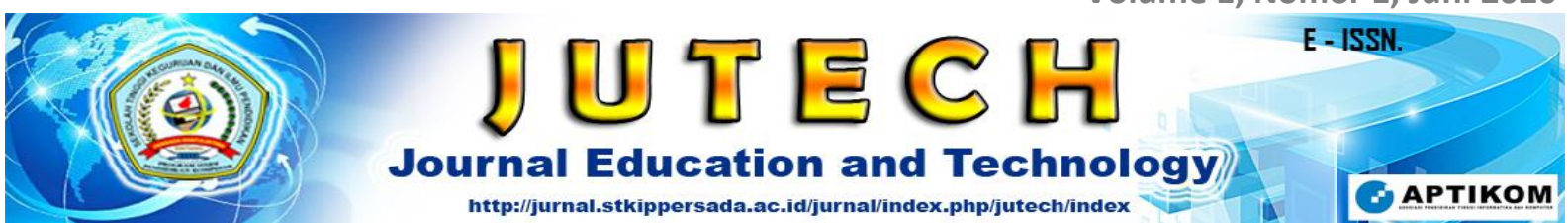

dari aspek pembelajaran, aspek isi, aspek tampilan dan aspek pemrograman. Hasil validasi para ahli dijadikan tolak ukur tentang layak tidaknya media pembelajaran untuk diujicobakan di lapangan.

Persentase hasil penilaian kelayakan dari ahli materi I dengan kriteria sangat layak, yaitu dengan persentase rata-rata sebesar $80,33 \%$. Sedangkan persentase hasil penilaian kelayakan dari ahli materi II dengan kriteria layak, yaitu dengan persentase rata-rata sebesar $78,05 \%$ dapat dilihat pada tabel 1 dan tabel 2 .

Tabel 1. Data Hasil Penilaian Ahli Materi I

\begin{tabular}{|c|c|c|c|c|c|c|c|c|c|}
\hline \multirow[t]{2}{*}{ No } & \multirow[t]{2}{*}{ Aspek } & \multicolumn{4}{|c|}{ Frekuensi } & \multirow{2}{*}{$\sum_{\text {Bobot }}$} & \multirow{2}{*}{$\sum_{\text {butir }}$} & \multirow{2}{*}{$\begin{array}{c}\text { Bobot } \\
\text { Max }\end{array}$} & \multirow[t]{2}{*}{$\%$} \\
\hline & & 1 & 2 & 3 & 4 & & & & \\
\hline 1 & Kualitas materi & & & 9 & & 27 & 9 & 36 & 75 \\
\hline 2 & Kemanfaatan materi & & & 2 & 4 & 22 & 6 & 28 & 85,33 \\
\hline \multicolumn{6}{|c|}{ Jumlah } & 49 & 15 & 64 & \\
\hline
\end{tabular}

Tabel 2. Data Hasil Penilaian Ahli Materi II

\begin{tabular}{|c|c|c|c|c|c|c|c|c|c|}
\hline \multirow[t]{2}{*}{ No } & \multirow[t]{2}{*}{ Aspek } & \multicolumn{4}{|c|}{ Frekuensi } & \multirow{2}{*}{$\sum_{\text {Bobot }}$} & \multirow{2}{*}{$\underset{\text { butir }}{\sum_{\text {f }}}$} & \multirow{2}{*}{$\begin{array}{c}\text { Bobot } \\
\text { Max }\end{array}$} & \multirow[t]{2}{*}{$\%$} \\
\hline & & 1 & 2 & 3 & 4 & & & & \\
\hline 1 & Kualitas materi & & & 6 & 3 & 30 & 9 & 39 & 80 \\
\hline 2 & Kemanfaatan materi & & & 2 & 4 & 22 & 6 & 28 & 75,5 \\
\hline \multicolumn{6}{|c|}{ Jumlah } & 52 & 15 & 60 & \\
\hline
\end{tabular}

Persentase hasil penilaian kelayakan dari ahli media I dengan kriteria layak, yaitu dengan persentase rata-rata sebesar 75,03 Sedangkan persentase hasil penilaian kelayakan dari ahli media II dengan kriteria sangat layak, dengan persentase rata-rata sebesar $82 \%$ dapat dilihat pada tabel 3 dan tabel 4.

Tabel 3. Data Hasil Penilaian Ahli Media I

\begin{tabular}{|c|c|c|c|c|c|c|c|c|c|}
\hline $\mathrm{N}$ & \multirow[t]{2}{*}{ Aspek } & \multicolumn{4}{|c|}{ Frekuensi } & \multirow{2}{*}{$\sum_{\text {bobot }}$} & \multirow{2}{*}{$\sum_{\text {butir }}$} & \multirow{2}{*}{$\begin{array}{l}\text { bobotM } \\
\text { ax }\end{array}$} & \multirow[t]{2}{*}{$\%$} \\
\hline o & & 1 & 2 & 3 & 4 & & & & \\
\hline 1 & $\begin{array}{ll}\text { Tampilan } & \text { media } \\
\text { pembelajaran } & \end{array}$ & & 3 & 8 & & 30 & 11 & 41 & 73,17 \\
\hline 2 & penggunaan bahasa & & 2 & 4 & & 16 & 6 & 22 & 72,72 \\
\hline 3 & Perwajahan & & & 5 & & 15 & 5 & 20 & 75 \\
\hline 4 & Pengorganisasian & & & 6 & & 18 & 6 & 22 & 81,81 \\
\hline \multicolumn{6}{|c|}{ Jumlah } & 94 & 27 & 108 & \\
\hline
\end{tabular}




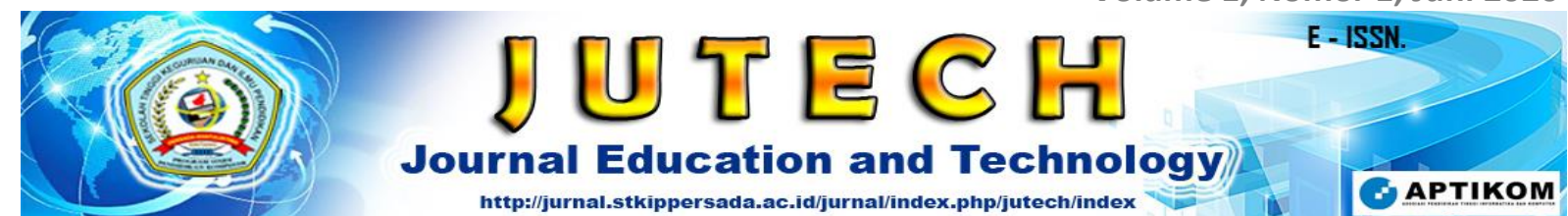

Tabel 4. Data Hasil Penilaian Ahli Media II

\begin{tabular}{|c|c|c|c|c|c|c|c|c|c|}
\hline $\mathrm{N}$ & \multirow[t]{2}{*}{ Aspek } & \multicolumn{4}{|c|}{ Frekuensi } & \multirow{2}{*}{$\sum_{\text {bobot }}$} & \multirow{2}{*}{$\sum_{\text {butir }}$} & \multirow{2}{*}{$\begin{array}{l}\text { bobot } \\
\text { Max }\end{array}$} & \multirow[t]{2}{*}{$\%$} \\
\hline $\mathrm{o}$ & & 1 & 2 & 3 & 4 & & & & \\
\hline 1 & $\begin{array}{l}\text { Tampilan } \\
\text { pembelajaran }\end{array}$ & & & 7 & 3 & 33 & 10 & 43 & 81,09 \\
\hline 2 & penggunaan bahasa & & & 4 & 1 & 16 & 5 & 21 & 79,19 \\
\hline 3 & Perwajahan & & & 3 & 1 & 13 & 4 & 17 & 80 \\
\hline 4 & Pengorganisasian & & & 2 & 4 & 22 & 6 & 28 & 83,07 \\
\hline \multicolumn{6}{|c|}{ Jumlah } & 84 & 25 & 109 & \\
\hline
\end{tabular}

Media pembelajaran interaktif materi keindahan alam negeriku direvisi berdasarkan saran dari pakar, kemudian diujicobakan pada siswa. Uji coba pada siswa dilakukan dua kali yaitu uji coba skala kecil yang dilakukan pada 16 orang siswa dari kelas IV Sekolah Dasar Negeri 03 Sintang dan uji coba skala luas yang dilakukan pada 26 orang siswa kelas IV Sekolah Dasar Negeri 01 Ketungau.

Media pembelajaran interaktif materi keindahan alam negeriku sangat layak sebagai media pembelajaran menurut pakar media dan pakar materi. Persentase kelayakan berdasarkan penilaian ahli materi Idiperoleh 75,03\% termasuk dalam kategori sangat layak. Persentase kelayakan berdasarkan penilaian ahli materi II diperoleh 80,33\% termasuk dalam kategori layak. Persentase kelayakan berdasarkan penilaian ahli media I diperoleh $82 \%$ termasuk dalam kategori layak. Persentase kelayakan berdasarkan penilaian ahli media II diperoleh $87,03 \%$ termasuk dalam kategori sangat layak.

$$
\text { Respon guru terhadap media }
$$
pembelajaran interaktif secara garis besar menunjukkan bahwa bahan ajar yang digunakan sudah baik. Hal ini terlihat dari hasil uji coba skala kecil diperoleh respon guru sebesar 75,08\% sedangkan pada uji coba skala luas diperoleh sebesar $85,75 \%$.

$$
\text { Respon siswa terhadap media }
$$
pembelajaran interaktif pada uji coba skala kecil diperoleh $81,75 \%$. Sedangkan pada uji coba skala luas diperoleh $84 \%$. Hal ini menunjukkan bahwa tanggapan siswa terhadap media pembelajaran interaktif termasuk dalam kriteria sangat baik.

\section{SIMPULAN}

Berdasarkan hasil penelitian dan pembahasan, maka dapat disimpulkan sebagai berikut: Media pembelajaran interaktif berbasis power point sangat layak. Persentase kelayakan berdasarkan penilaian ahli materi I diperoleh $75,03 \%$ termasuk dalam kategori layak dan ahli materi II diperoleh $80,33 \%$ termasuk dalam kategori layak. Sedangkan persentase kelayakan berdasarkan penilaian ahli media I diperoleh $82 \%$ termasuk dalam kategori layak dan ahli media II diperoleh 87,03\% termasuk dalam kategori sangat layak. Respon guru terhadap media interaktif berbais power point 


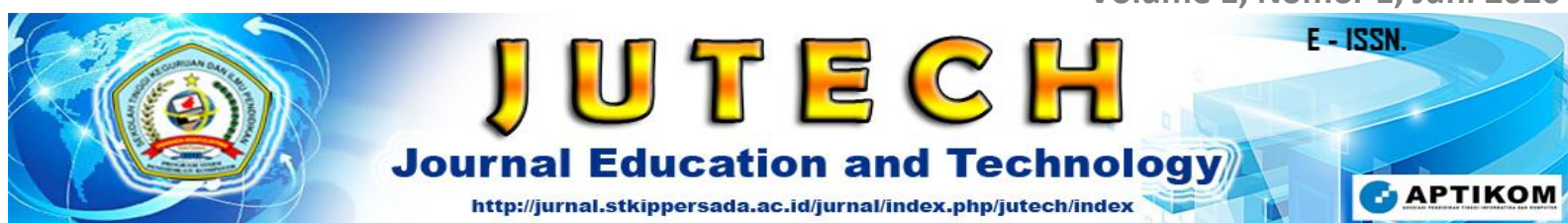

menunjukkan bahwa media yang digunakan sudah baik. Hal ini terlihat dari hasil uji coba skala kecil diperoleh respon guru sebesar $75,8 \%$ sedangkan pada uji coba skala luas diperoleh sebesar $85,75 \%$. Sedangkan respon siswa terhadap media pada uji coba skala kecil diperoleh $81,75 \%$ dan pada uji coba skala luas diperoleh $84 \%$. Hal ini menunjukkan bahwa tanggapan siswa terhadap media pembelajaran interaktif berbasis power point termasuk dalam kriteria sangat baik.

\section{DAFTAR RUJUKAN}

Aprianto, DA. 2014. Materi Pelatihan Guru Implementasi Kurikulum 2013 Tahun 2014. Kemendikbud 2014 (Internet). (diunduh 2014 Juni 18); HO-1.1. Tersedia pada https://www.kemendikbud.go.id

Arsyad, A. 2015. Media Pembelajaran. Jakarta: PT Raja Grafindo Persada.

Majid, Abdul. 2014. Pembelajaran Tematik Terpadu. Bandung: PT Remaja Rosdakarya.

Sudjana, N. 2009. Penilaian Hasil Proses Belajar Mengajar. Bandung: PT Remaja Rosdakarya.

Sugiyono. 2008. Metode Penelitian Kuantitatif Kualitatif dan $R \& D$. Bandung: Alfabeta.

2009. Metode Penelitian Kuantitatif Kualitatif dan $R \& D$. Bandung: Alfabeta.

2011. Metode Penelitian Kuantitatif Kualitatif dan $R \& D$. Bandung: Alfabeta.
Sukmadinata, N.S. 2010. Metode Penelitian Pendidikan. Bandung: PT. Remaja Rosdakarya.

Trianto. 2011. Desain Pengembangan Pembelajaran Tematik Bagi Anak Usia Dini TK/RA \& Anak Usia Kelas Awal SD/MI (Jurnal). Jakarta: Kencana.

Undang-Undang Nomor 20 Tahun 2003 Tentang Sistem Pendidikan Nasional Lembaran Negara Republik Indonesia Tahun 2003 Nomor 78. 2003. Jakarta. Sinar Grafika. 